\title{
ОЦІНКА ГЕОХІМІЧНОЇ РУХОМОСТІ СПОЛУК ВАЖКИХ МЕТАЛІВ У ВІДВАЛЬНИХ ШАХТНИХ ПОРОДАХ ЗАХІДНОГО ДОНБАСУ
}

\begin{abstract}
Проведено типізацію відвальних шахтних порід Західного Донбасу за величиною кислотно-лужного показнику водорозчинного комплексу. Встановлено, що саме породи 3 низьким значенням цього показнику характеризуються найбільшими величинами середнього вмісту водорозчинних форм важких металів. Доведено, що саме шахтні відвали с генеруючим джерелом забруднення важкими металами об'сктів довкілля цього регіону.

Ключові слова: відвальні шахтні породи, важкі метали.
\end{abstract}

Проведена типизация отвальных шахтных пород Западного Донбасса по величине кислотно-основного показателя воднорастворимого комплекса. Установлено, что именно породы с низким значеннем этого показателя характеризуются наибольшими величинами среднего содержания воднорастворимых форм тяжелых металлов. Доказано, что именно шахтные отвалы являются генерирующим источником загрязнения тяжелыми металлами объектов окружающей среды этого региона.

Ключевые слова: отвальные шахтные породы, тяжелье металлы.

Typification of turn mine breeds of Western Donbas is conducted after a size acid-lye the index of water-soluble complex. It is set that exactly breeds with the low value of it an index characterized the most sizes of middle content of water-soluble forms of heavy metals. It is well-proven that exactly mine dumps are the generating source of contamination of objects of environment of this region by heavy metals.

Keywords: turn mine breeds, heavy metals

Постановка проблеми. Вугільна промисловість України відноситься до найбільших забруднювачів довкілля. При цьому суттєвий вплив на довкілля завдається не лише безпосередньо в процесі видобутку вугілля, але протягом багатьох років після його завершення. Джерелом забруднення об' єктів довкілля $є$ породні відвали, які займають значні території родючих земель. Щорічно у відвали складується близько 40 млн. м відвальної шахтної породи. Більшість відходів вугледобувної промисловості мають потенційні токсичні та мутагенні властивості, оскільки вміщують значну кількість важких металів, які практично не піддаються біодеградації у довкіллі, і тому є особливо небезпечними для живих організмів [1-6].

Стан проблеми. Для кількісної оцінки забруднення відходів гірничодобувної промисловості важкими металами у більшості випадків зазвичай враховується їх валовий вміст. При цьому не береться до уваги, що значна частка важких металів міцно зв'язана 3 мінеральною матрицею та практично не бере участі у міграційних процесах. Але при оцінці екологічної небезпеки відходів важливо знати не стільки загальний вміст важких металів, скільки можливість їхнього переходу у ланцюгу «відходи - техногенні потоки важких металів-забруднювачів - навколишнє середовище».

Тому виключно важливе значення набуває оцінка геохімічної рухомості сполук важких металів, тобто їх властивість переходити з твердої фази до рідкої, мігрувати до природних ландшафтів та поглинатися рослинністю. Особливо це стосується водорозчинних форм металів, оскільки в умовах поверхневого 
складування відвальних шахтних порід у відвали, пріоритетним фактором, що регулює процеси міграції важких металів $є$ вилуговування атмосферними опадами твердої фази відходів. Саме наявність та вміст важких металів у водорозчинному комплексі характеризує їхню розчинність та міграційну активність та може бупи використана для оцінки реальних масштабів можливого забруднення гідросфери [7].

Викладення основного матеріалу. Спостереження та контроль вмісту водорозчинних форм важких металів проводилося на 290 зразках відвальних шахтних порід (ВШП) Західного Донбасу. Зразки відібрано із шахтних відвалів двох груп шахт Західного Донбасу - східної (шш. «Першотравнева», «Степова», «Дніпровська», «ім. Сташкова», «Ювілейна») та західної (шш. «Павлоградська», «Терновська», «Благодатна», «Західно-Донбаська» та «Героїв Космосу»). Відбір проб - точковий, проводився штуфним та горстковим способом [8] відповідно до ГОСТ 26450.0-85. Визначення погрішності відбору та обробки проб проводилося у відповідності із СТ СЕВ 4384-83.

Було проведено вивчення літологічних особливостей порід шахтних відвалів на території східної та західної групи шахт Західного Донбасу. Встановлено, що у мінералогічному складі зразків відвальних порід переважають уламкові та глинисті породи. Відомо, що вони складають верхню частину візейського ярусу, намюрський та бакширський яруси. Карбонатними породами складено лише турнейський ярус та нижня частина візейського ярусу нижнього карбону.

За речовим складом та текстурно-структурними особливостями у досліджених відвальних шахтних породах простежено переважно такі наступні літологічні різності порід, що відносяться до середнього та нижнього карбону:

- піщаники;

- алевроліти;

- глинисті породи;

- вуглисті аргіліти;

- конкреційні утворення (карбонатні конкреції, сульфіди, у т.ч. пірит).

Пірит зустрічається у вигляді невеликих прошарків, конкрецій, стяжок та одиничних кришталів. При віддаленні від лінії контакту порід з вугіллям кількість піриту помітно зменшується. Чисельний вміст у відвальних шахтних породах Західного Донбасу дрібнозернистих піщаників становить від $5 \%$ до $10 \%$, алевролітів та алевритових глин - від 18\% до $32 \%$, глинистих порід - від $38 \%$ до $40 \%$, вуглистих алевролітів - від $15 \%$ до $21 \%$, піритових та карбонатних конкрецій - від 5\% до $10 \%$.

Проведений хімічний аналіз порід показав, що серед досліджених зразків 10 \% шахтних порід мають величину кислотно-лужного показника водної витяжки $(\mathrm{pH})$ менше 5. Значення $\mathrm{pH}$ водної витяжки для інших шахтних порід становить від 5 до 8, тобто характеризується нейтральною реакцією.

Для визначення водорозчинних форм важких металів як екстрагент використовували дистильовану воду при постійному перемішуванні протягом 3 хв. Співвідношення твердої та рідкої фаз складало 1:5. За допомогою фільтрування тверду фазу відокремлювали від рідкої та методом атомно-абсорбційної спектрофотометрії [9] визначали у останній вміст водорозчинних форм наступних металів: міді, свинцю, цинку, кадмію, марганцю, хрому, заліза, нікелю та кобальту.

Отримані дані щодо мікрокомпонентного складу відвальних порід на усіх досліджених ділянках об'єднані у два статистичних масиви, які відрізнялися між собою за величиною $\mathrm{pH}$ водної витяжки (породи 3 кислою та нейтральною 
реакцією водної витяжки). Результати статистичної обробки даних наведено у таблиці.

3 даних таблиці видно, що вміст у ВШП практично усіх досліджених важких металів має широкий діапазон коливань. Особливо це характерно для порід 3 нейтральною реакцією водної витяжки Вміст кадмію та хрому у цих породах відрізнявся у 30-40 разів, а цинку та нікелю - більш, ніж у 100 разів. Для свинцю, міді та кобальту ця різниця склала понад 330 разів. Найбільші коливання вмісту важких металів (понад 1000 разів) відмічено для марганцю та нікелю.

Різниця між мінімальними та максимальними значеннями вмісту важких металів у породах з кислою реакцію водної витяжки також є значною, але у 3-4 рази меншою, ніж для порід з величиною $\mathrm{pH}>5$.

Порівняльний аналіз вмісту водорозчинних форм важких металів у породах різного типу свідчить про те, що основними постачальниками важких металів у довкілля $\epsilon$ саме породи 3 кислою реакцією водної витяжки, вихідний мінералогічний склад яких характеризується значним вмістом піриту. Саме у цих

Таблиия

Вміст водорозчинних форм важких металів у породах Західного Донбасу

\begin{tabular}{|l|c|c|c|c|c|c|}
\hline \multirow{2}{*}{ Елемент } & \multicolumn{6}{|c|}{ Вміст металу у породі, мкг $/ 100$ г } \\
\cline { 2 - 7 } & \multicolumn{2}{|c|}{ Середній } & \multicolumn{2}{c|}{ Мінімальний } & \multicolumn{2}{c|}{ Максимальний } \\
\cline { 2 - 7 } & $\mathrm{pH}>5$ & $\mathrm{pH}<5$ & $\mathrm{pH}>5$ & $\mathrm{pH}<5$ & $\mathrm{pH}>5$ & $\mathrm{pH}<5$ \\
\hline $\mathrm{Cu}$ & 10,81 & 109,83 & 0 & 11,00 & 340,00 & 484,00 \\
\hline $\mathrm{Pb}$ & 24,90 & 49,32 & 0 & 15,00 & 335,00 & 220,00 \\
\hline $\mathrm{Zn}$ & 64,66 & 295,24 & 7,50 & 144,00 & 800,00 & 570,00 \\
\hline $\mathrm{Cd}$ & 3,16 & 6,73 & 0 & 0,50 & 30,00 & 19,00 \\
\hline $\mathrm{Mn}$ & 200,96 & 882,14 & 3 & 177,00 & 1350,00 & 1980,00 \\
\hline $\mathrm{Cr}$ & 6,26 & 19,47 & 0 & 4,50 & 43,50 & 50,00 \\
\hline $\mathrm{Fe}$ & 145,43 & 795,83 & 10,00 & 67,50 & 1150,00 & 2125,00 \\
\hline $\mathrm{Ni}$ & 44,98 & 456,31 & 0 & 7,00 & 829,00 & 1860,00 \\
\hline $\mathrm{Co}$ & 24,45 & 189,17 & 0 & 22,50 & 380,00 & 600,00 \\
\hline
\end{tabular}

породах спостерігається найбільш високий вміст усіх без винятку важких металів. Так, кількість кобальту, міді та нікелю у породах 3 кислою реакцією водної витяжки практично на порядок (у 8-10 разів) перевищує ці ж показники для порід 3 нейтральною реакцію водної витяжки. Співвідношення вмісту заліза, марганцю та цинку у пробах шахтних порід з нейтральною та кислою реакцією водної витяжки становить 1:4 та 1:5. Вміст хрому, свинцю та кадмію для проб порід 3 кислою реакцією водної витяжки виявився у 2-3 рази більшим у порівнянні з нейтральною (рис. 1). 


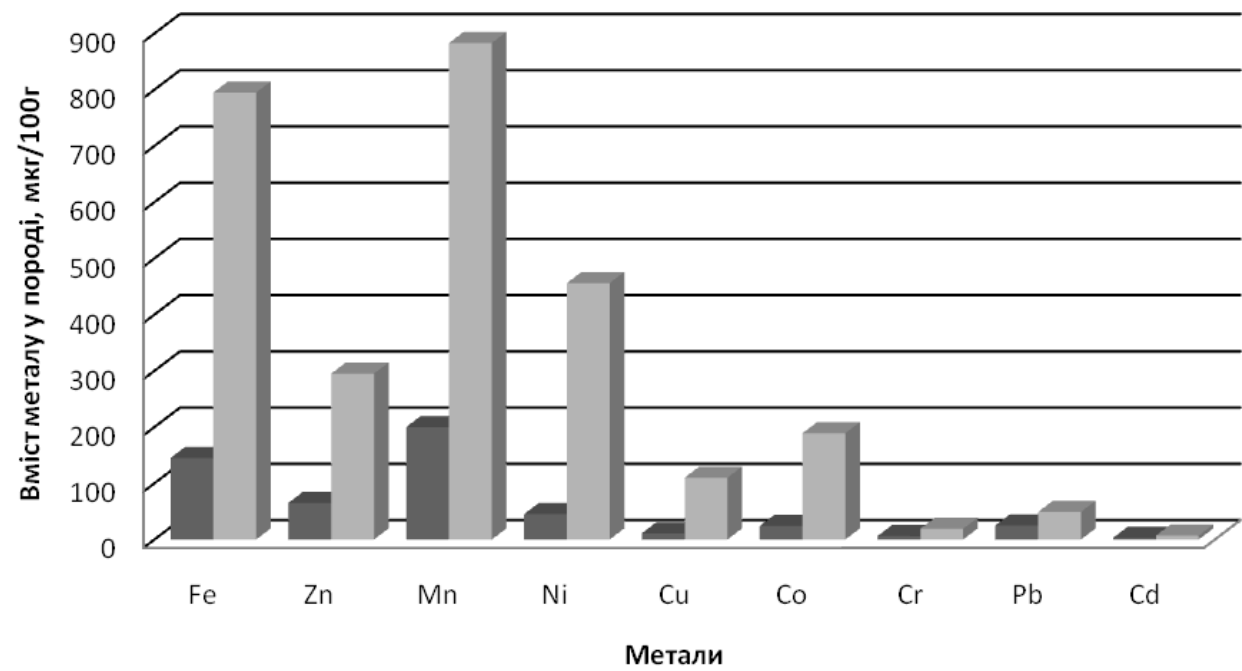

— Породи з нейтральною реакцією водної витяжки

п Породи з кислою реакцією водної витяжки

Рис. 1. Вміст водорозчинних форм важких металів у відвальних шахтних породах Західного Донбасу

Як видно з рисунку, у відвальних породах як з нейтральною, так і 3 кислою реакцію водної витяжки, найбільшим вмістом серед досліджених металів характеризується залізо, вміст якого $\epsilon$ тісно пов'язаним зі складом породоутворюючих мінералів, зокрема піриту. Кількість цього металу перевищила показник 500 мг/100 г породи у 10\% проб з нейтральною та у $70 \%$ проб з кислою реакцію водної витяжки, а 5\% таких проб містять заліза понад 2000 мг/100 г породи.

Марганець також присутній у значній кількості в усіх без винятку пробах досліджених відвальних порід; 80 \% порід з нейтральною реакцію водної витяжки містить від 50 до 100 мг/100 г цього металу, але у $5 \%$ проб його кількість становить від 500 до 1000 мг/100 г породи. Для порід, які мають кислу реакцію водної витяжки кількість проб у такому діапазоні концентрацій марганцю є ще вищою та становить понад $50 \%$.

До трійки найбільш розповсюджених металів у породах 3 нейтральною реакцію водної витяжки відноситься і цинк, який відзначається високою міграційною здатністю. У $60 \%$ відвальних порід такого типу вміст цинку не перевищує 50 мг/100 г породи, але для 17 \% проб ця величина становить більше 100 мг/100 г породи. У породах з кислою реакцією водної витяжки слід відмітити достатньо високий вміст нікелю (максимальні величини понад 1000 мг/100 г породи визначено у $10 \%$ проб). Мідь, свинець та кобальт також присутні у відвальних породах, але їх вміст є значно меншим та змінюється від 0 до 380 мкг/100 г у породах з нейтральною реакцію водної витяжки, та від 11 до 600 мкг/100 г у породах порід, які мають кислу реакцію водної витяжки. Кількість хрому та кадмію у породах обох типів $є$ дуже незначною та для більшості проб не перевищує 50 мкг/100 г породи. 
Необхідно також зазначити, що не всі досліджені породи 3 нейтральною реакцію водної витяжки містять в своєму складі увесь спектр важких металів, що визначався. Так, у $17 \%$ досліджених порід, які мають нейтральну реакцію водної витяжки, взагалі відсутні такі метали, як кадмій, хром та свинець. Кобальту та заліза не містять понад 4 \% порід. У породи 3 кислою реакцією водної витяжки присутні усі без винятку досліджені важкі метали.

Таким чином, встановлено, що досліджені породи Західного Донбасу вміщують в своєму складі значну кількість водорозчинних форм марганцю, нікелю, цинку, заліза, свинцю. Кількість міді, кадмію, хрому, кобальту є значно нижчою. За середніми величинами вмісту водорозчинних форм метали можуть бути розташовані у наступні ряди:

$\mathrm{Mn}>\mathrm{Fe}>\mathrm{Pb}>\mathrm{Zn}>\mathrm{Ni}>\mathrm{Cd}>\mathrm{Cr}>\mathrm{Co}>\mathrm{Cu}$ (для порід з нейтральною реакцією водної витяжки)

$\mathrm{Mn}>\mathrm{Fe}>\mathrm{Zn}>\mathrm{Ni}>\mathrm{Cu}>\mathrm{Pb}>\mathrm{Co}>\mathrm{Cr}>\mathrm{Cd}$ (для порід 3 кислою реакцією водної витяжки).

Висновки. Таким чином, проведено типізацію відвальних шахтних порід Західного Донбасу за величиною кислотно-лужного показнику водорозчинного комплексу. Встановлено, що саме ВШП з низьким значенням цього показнику характеризуються найбільшими величинами середнього вмісту водорозчинних форм усіх без винятку досліджених важких металів. Особливу небезпеку для довкілля становить наявність у породах цього типу міграційноздатних форм важких металів I класу небезпеки - свинцю, кадмію, цинку, середній вміст яких становить від 500 до 1500 мкг/100 г породи. Доведено, що саме ВШП є генеруючим джерелом забруднення важкими металами об'єктів довкілля цього регіону та становлять потенційну небезпеку здоров’ю населення.

\section{Бібліографічні посилання}

1. Бутовецкий В. С. Охрана природы при обогащении углей / В. С. Бутовецкий. - М.: Недра. - 1991. - 231 с.

2. Доброгорский Н. А. Результаты исследования токсичности породного отвала шахты “Лесная" / Н. А. Доброгорский, И. И. Курмелев, В. П. Шевченко // Уголь Украины. - 1998. - № 8-9. - С. 25-26.

3. Курмелев И. И. Прогноз содержаний токсичных элементов в продуктах обогащения (теоретический баланс) / И. И. Курмелев // Сб. науч. тр. НГА Украины «Актуальные проблемы геологии». - Днепропетровск, 1999. - Т. 1. - № 6. C. $186-187$.

4. Доброгорский Н. А. К вопросу о токсичности отходов угледобычи / Н. А. Доброгорский, И. И. Курмелев, В. П. Шевченко // Придніпровський науковий вісник. - Днепропетровск, 1998. - № 83. - С. 49-50.

5. Ишков В. В. О прогнозе содержаний токсичных элементов в продуктах угледобычи Чистяково-Снежнянского геолого-промышленного района Донбасса / В. В. Ишков, И. И. Курмелев // Науковий вісник Національної гірничої академії України. - Днепропетровск, 1999. - № 2. - С. 37-40.

6. Доброгорский Н. А. Эколого - экономические и социальные аспекты проблемы утилизации отходов углеобогащения / Н. А. Доброгорский, И. И. Курмелев, В. П. Шевченко // Придніпровський науковий вісник. Днепропетровск, 1998. - № 83. - С. 100-101. 
7. Рылов В. Г. Методика опробования месторождений полезных ископаемых / В. Г. Рылов, А. В. Труфанов. - Ростов-на-Дону, 2013. - 99с.

8. Черных Н. А. Тяжелые металлы и радионуклиды в биогеоценозах / Н. А. Черных, М. М. Овчаренко. - М., 2002. - 200 с.

9. Карякин А. В. Методы оптической спектроскопии и люминесценции в анализе природных и сточных вод / А. В. Карякин, И. Ф. Грибовская. M., 1987.- 304 c.

Надійшла до редколегії 05.03.2014 p. 